\title{
개도국과의 성과 파트너십 구축 방안
}

조 정 명 (KOICA 평가실 과장)

\section{목 차}

1. 들어가는 말

2. 국제사회의 담론 : 개도국과의 성과 파트너십

3. $\mathrm{KOICA}$ 의 개도국과의 성과 파트너십

3.1 개도국과의 성과 파트너십 추진 배경

3.2. 개도국과의 성과 파트너십 사례

4. 시사점

5. 맺음말

\section{1. 들어가는 말}

사전적 의미의 파트너십(partnership)이란, 서로 다른 집단들(parties)이 동일한 목표달성 을 위해 또는 공동의 이익(interest) 추구를 위해 서로 협력하는 관계를 의미한다. 여기에서 파트너(partner)란 이러한 관계에 관련된 이해당사자 중에서도 파트너십을 유지하기 위한 거 버넌스(governance)와 재정(finance)에 관련된 이해관계자를 일컫는다. 파트너십은 그 자체 가 목적일 수도 있고, 공동의 목표를 효율적으로 달성하기 위한 수단으로 활용되기도 하는데, 이는 국제개발협력 분야에서도 마찬가지이다. '글로벌 파트너십'은 새천년개발목표(Millennium Development Goals, MDGs)1)중의 하나로 그 자체가 목적이기도 하며, 개발목표 달성은 다양 한 개발협력 주체들의 협력을 요한다는 측면해서 목표달성을 위한 수단이기도 하다. 
최근 국제개발협력 분야에 있어 파트너십은 그 중요성이 점차 강조되고 있으며, 대상 범위 와 주체 또한 점점 확대되고 있는 추세이다. 국제사회는 글로벌 파트너십의 이행을 위해 2003 년 원조효과작업반(Working Party on Aid Effectiveness, WP-EFF)의 출범이래로, 로마에 서 부산에 이르기까지2) 지속적인 협의와 선언을 통해 개발의 목표와 의무를 공유하고, 다양한 주체간의 협력을 중심으로 하는 새로운 국제개발협력의 패러다임을 구축해 가고 있다. 특히 2011년 부산총회 결과로 “효과적인 개발협력을 위한 글로벌 파트너십(Global Partnership for Effective Development Cooperation, GPEDC)"이 출범하여, 원조의 효과성 제고를 위한 글 로벌 파트너십 구축의 중요성이 재차 강조되었다.

파트너십의 참가 주체에 따라 다양한 파트너십이 정의될 수 있으나, 특히 수원국과의 파트 너십은 가장 기초적이고도 결정적인 파트너십으로 인식되고 있다. 이는 사업추진 과정의 효율 화와 성공적인 사업성과 관리를 위한 필수 요소이기 때문이다. 수원국의 역할과 수원국과의 협력을 강조하는 인식의 변화는 국제사회가 수원국을 명명하는 방식에서도 파악할 수 있다. 먼저, 파리선언 및 아크라행동강령에서는 수원국을 recipient country가 아닌 partner country로 명시하여 수원국과 공여국을 주종관계가 아닌 동반자적 관계로 인정하는 인식의 변화를 반영하였다. 부산파트너십에서는 국가, 국제기구 등과 같은 전통적인 국제개발협력 주체 이외 에 민간분야, 시민사회 등을 국제개발협력의 주요 행위자로 포함하면서 민간분야의 파트너와 의 혼선을 줄이기 위해 수원국을 developing country로 명시하였다3). 수원국에서 파트너로, 파트너에서 개발도상국으로의 명칭 변화는 수원국을 개발협력의 대상에서 협력자로, 그리고 단순 협력자를 넘어 주도적인 참여 주체로 인지하는 국제사회의 인식의 변화를 보여주는 것이 다(부산파트너십의 합의결과를 존중하여, 이하 수원국은 개발도상국, '개도국'으로 표기하기로 한다). 개도국과 파트너십의 중요성은 부산총회 결과문에서도 재차 강조되었다. 부산 글로벌 파트너십의 4대 개발협력 공통원칙은 $\boldsymbol{\Delta}$ 개발 우선과제에 대한 개도국의 주인의식, $\boldsymbol{\Delta}$ 결과중 심, $\boldsymbol{\Delta}$ 포괄적 개발 파트너십, $\boldsymbol{\Delta}$ 투명성 및 상호 책무성으로 정리된다. ${ }^{4)}$ 이는 개도국을 국제개

1) 새천년개발목표(Millennium Development Goals, MDGs)는 2000년 UN에서 채택된 의제로, 2015년까지 빈곤을 반으 로 감소시키자는 범세계인 약속이다. 주요 내용으로 (1)절대빈곤과 기아퇴치, (2)초등교육의 완전보급, (3)성평등 촉진과 여권 신장, (4)아동 사망률 감소, (5)모성건강 개선, (6HIV/AIDS, 말라리아 등의 각종 질병 퇴치, (7)지속가능한 환경보장, (8)개발을 위한 글로벌 파트너십 구축을 들 수 있다.

2) $\mathrm{OECD}$ 개발원조위원회(DAC)주관으로 개최되는 국제 개발원조 분야 최고위급 회의로 원조조화에 관한 로마선언Rome Declaration on Harmonization(2003), 원조의 효과성에 대한 파리선언Paris Declaration on Aid Effectiveness(2005), 아크라 행동강령Accra Agenda for Action(2008), 효과적 개발협력에 대한 부산총회Busan(2011) 등이 진행되어 왔다.

3) 수원국에 대한 선언적 명칭은 변화하였으나, 국내적으로는 파트너와 개발도상국이 포함하는 대상의 범위가 넓고(가령, 중 진국 등도 개발도상국에 포함됨) 명명하는 주체가 구체적이지 않아 수원국, 파트너, 개발도상국을 수원국으로 통칭하여 부르는 것이 보편적이다. 
발협력의 중심 주체로 인식하고, 그들의 주체성과 참여정도가 보다 심화되어야 함을 간접적으 로 나타내고 있다. 또한 이는 개도국을 중심으로 하는 파트너십을 강조했다는 측면에서 개도 국의 주체의식과 공여국-개도국간의 형평적 파트너십을 강화하는 것으로 해석할 수 있다.

이와 같이 개도국과의 파트너십은 국제개발의 기본 원칙이자 행동양식으로 인식되고 있으 며, 이는 정책 및 전략 수립과 같은 거시적 차원에서 사업의 집행 및 관리에 이르는 미시적 차 원까지 국제개발 전반에 거쳐 고려되고 강조되고 있다. 특히 결과중심 원칙이 재차 강조됨에 따라 진행사항에 대한 결과중심의 관리, 모니터링, 평가, 그리고 커뮤니케이션 방식의 개선 등 이 요구되고 있다. 이에 따라 국제사회에서는 개도국이 주도하는 현장중심의 공동 성과관리 기반 및 도구 마련을 위한 움직임이 계속 되고 있으며, 개도국의 기존 시스템을 최대한 활용하 여 공동 실행계획을 수립하고 성과를 모니터링 할 것을 권장하고 있다.

그렇다면 성과관리 부문에 있어 우리나라의 개도국과의 파트너십 현황은 어떠한가? 성과관 리에 있어 전반적으로 우리나라의 개도국과의 파트너십 현황은 다소 제한적이라 할 수 있다. 2010년 OECD DAC(Development Assistance Committee)에 가입과 함께 우리나라 개발원조 정책 및 체계의 선진화가 본격화됨에 따라 성과관리 및 개도국과의 파트너십 또한 강화되기 시작하였다. 2010 년 이래 국제사회의 담론에 적극적으로 참여하고, 현실적인 수준의 개발협력 사업의 현장화 및 성과관리 체계 강화를 통해 비교적 단기간에 많은 성과를 이루었다. 그러나 성과관리 부문의 개도국과 파트너십은 개도국의 참여정도(depth of participation)가 다소 제 한되어 있어 지속적인 파트너십 강화 방안 마련이 필요한 실정이다.

한국국제협력단은 국내 무상원조 전담기관으로서 성과관리체계 고도화 및 선진화에 앞장서 고 있으며, 개도국과의 성과관리부문 파트너십 구축부문에 있어서도 제한적이나 의미 있는 성 과를 거두었다. 이에 본고에서는 협력단의 성과관리 부문 개도국과의 파트너십 사례를 소개하 고 이의 시사점을 탐색하여, 기존의 공여국 위주의 성과관리 관점 및 방식에서 전환하여 개도 국이 참여하는 성과관리 파트너십 강화를 위한 구체적인 통로를 제시하고자 한다.

4) 관계부처 합동(2012). 부산 글로벌 파트너십 출범과 향후 추진계획. 제13차 국제개발협력 위원회. 


\section{2. 국제사회의 담론 : 개도국과의 성과 파트너십}

성과관리는 정책 또는 사업의 기획-시행-평가까지의 전반에 거쳐 이루어진다. 따라서 파트 너십에 기반을 둔 성과관리를 위해서는 이해관계자 간에 정책 또는 사업의 전반에 걸친 협력 이 필요하다. 기획단계에서는 추진 목표 및 성과관리 체계 및 도구에 대한 사전합의가 필요하 며, 시행단계에서는 사전 동의한 성과관리 틀을 활용하여 지속적인 모니터링 및 결과 공유가 필요하다. 평가단계에서는 공동평가를 통해 성과에 대한 상호 책무성을 확보하고, 그 결과를 추후 정책 또는 사업추진에 반영하여 체계적인 성과관리를 실현할 수 있다.

개도국과의 성과관리 파트너십 여부는 부산 글로벌 파트너십의 평가지표에도 포함되어 있 어, 향후 공여국의 원조활동 결과를 평가하는 주요 지표중 하나이다. 개도국과의 성과관리 파 트너십은 다양한 측면에서 정의될 수 있으나, 부산 글로벌 파트너십의 평가지표에서는 '개도 국 우선사항을 충족하는 결과중심의 협력'으로 정의하고 있으며, 이는 개도국 결과 프레임워 크(result framework)를 사용하는 공여국 비율로 측정한다.

결과 프레임워크(result framework)는 성과를 모니터링하고 관리하기 위한 일종의 틀로, 이는 정책 또는 사업을 통해 달성하고자 하는 성과와 목표치(target) 그것을 입증하기 위한 지 표(indicator) 및 수단(means of verification), 주요가정(assumption) 등을 포함한다. 같은 맥락에서 개도국 결과 프레임워크란 개발정책 및 사업의 성과와 그것을 관리하기 위한 모니터 링 및 평가 체계 전반을 일컫는 것으로, 중요한 것은 공여국으로부터 주입된 것이 아닌 개도국 을 중심으로 이해관계자들 참여와 합의를 통해 개발된 자발적 시스템 이라는 점이다. 〈표 1〉

에서 알 수 있듯이 동 지표의 측정 방법은 $\frac{\text { 개도국 결과 프레임워크를 사용하는 공여국수 }}{\text { 전체 공여국 수 }}$ 개도국 결과 프레임워크를 사용하는 공여국 비율이 상승하기 위한 전제조건은 개도국의 자체 결과 프레임워크가 존재한다는 것이다. 공여국이 개도국 결과 프레임워크를 사용할 의지가 있 더라도 개도국의 결과프레임 워크가 존재하지 않으면 사용할 수 없기 때문이다. 이는 공여국 으로 하여금 기존의 개도국 결과 프레임워크의 사용을 권장함은 물론이고, 개도국의 전반적인 모니터링 및 평가 시스템 강화에 기여할 수 있도록 의도하고 있는 것이다(임소진, 2012). 
〈표 1〉부산 글로벌 파트너십 평가지표 및 정의5)

\begin{tabular}{|c|c|}
\hline & 부산 글로벌 파트너십 이행을 위한 10 대 평가지표 \\
\hline 지표 1 & 개도국 우선사항을 충족하는 결과중심의 협력 \\
\hline 정의 & 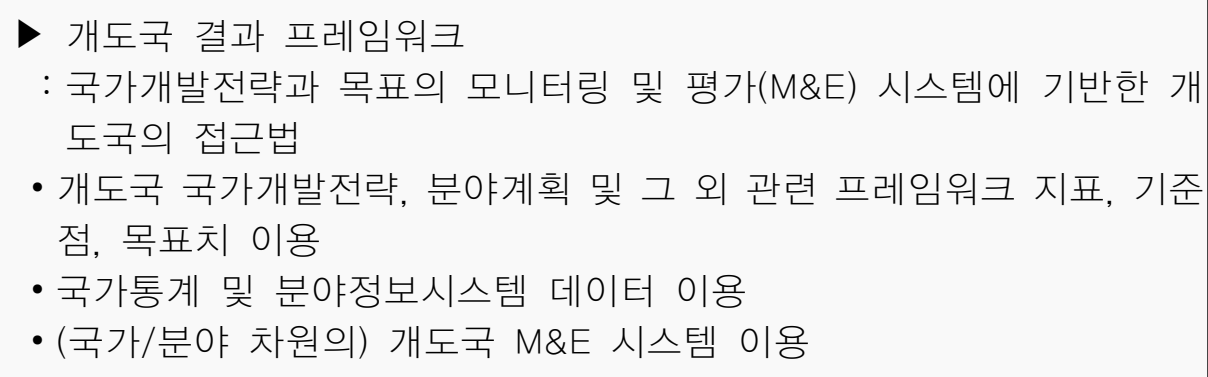 \\
\hline 평가방법 & $\begin{array}{l}\text { 개도국 결과 프레임워크를 사용하는 공여국 비율 } \\
\text { - 공여국의 개도국 결과 프레임워크 사용비율은 이후 ‘이용안함' '부분 } \\
\text { 적 이용', '완전한 이용'으로 나누어 점수화 될 예정임 }\end{array}$ \\
\hline & 분자 $\quad$ 개도국 결과 프레임워크를 사용하는 공여국 수 \\
\hline$\neg$ ○о & \begin{tabular}{l|l} 
분모 & 전체 공여국 수
\end{tabular} \\
\hline 목표치 & 개도국 내 모든 공여국이 개도국 결과 프레임워크 이용 \\
\hline 지표 2 & 개발활동의 참여와 기여를 최대화 하는 환경에서의 시민사회 운영 \\
\hline 지표 3 & 개발을 위한 민간부문의 참여와 기여 \\
\hline 지표 4 & 투명성 : 개발협력에 관한 정보 공개 \\
\hline 지표 5a & 개발협력 예측성(1년) \\
\hline 지표 5b & 개발협력 예측성(중기) \\
\hline 지표 6 & 의회의 정밀검토에 따른 정부의 원조예산 \\
\hline 지표 7 & 포괄적 검토에 의한 개발협력 주체간 상호책무성 강화 \\
\hline 지표 8 & 양성평등과 여성역량강화 \\
\hline 지표 9a & 개도국 공공재정 시스템의 질 \\
\hline 지표 9b & 개도국 공공재정 시스템 및 공공조달시스템 이용 \\
\hline 지표 10 & 원조비구속성 \\
\hline
\end{tabular}

5) 임소진(2012). 한국 ODA의 부산 글로벌 파트너십 평가지표 이행방안. 개발협력 정책과 이슈 제 15 호. 한국국제협력단 
개도국 결과 프레임워크는 단일 개도국을 대상으로 하는 정책 또는 사업 집행시 적용가능하 다. 그러나 단일 개도국을 대상으로 한 프로그램 이외에도, 다양한 이해관계자들이 모여 조직 하는 GRPPs(Global Regional Partnership Programs) 또한, 개발원조를 지원하는 하나의 대 표적인 모델(modality)이 되었다. GRPPs는 범세계적 이슈 해결을 위한 조직된 집단적 행동 (collective action)을 의미하는 것으로, 이 용어는 세계은행(World Bank, WB)에 의해 사용되 기 시작하였다. GRPPs는 $\boldsymbol{\Delta}$ 공통된 목표달성을 위해 파트너들이 재정, 기술, 인적 자원을 공 동 출자한다는 점, $\boldsymbol{\Delta}$ 프로그램의 활동 범위가 한 국가에 국한되지 않다는 점, $\boldsymbol{\Delta}$ 파트너십 수행 을 위해 파트너들이 거버넌스 체계와 관리 기능을 갖춘 새로운 조직을 신설한다는 점에서 프 로그램형 파트너십(programmatic partnership)이다(WB, 2007). GRPPs는 그 규모나 범위는 다양하지만, 대부분 섹터나 주제별로 형성되기 마련인데, GRPPs에는 거버넌스 차원에서 다양 한 파트너들이 참여하여 공동 의사결정 및 책임을 진다는 차원에서 성과관리의 체계 또한 기 존의 방식과는 차별화 되어야 하는 필요성이 제기되었다. 이에 $\mathrm{OECD} / \mathrm{DAC}$ 의 개발평가네트워 크(Network on Development Evaluation)는 2007년 WB의 독립평가그룹(Independent Evaluation Group, IEG)을 중심으로 GRPPs 평가를 위한 원칙 및 기준을 수립하였다. 이는 새로운 평가기준을 개발한 것이 아니라, 기존에 개발평가의 원칙 및 기준을 파트너십의 환경 (context)에 맞게 종합 정리한 것이다. 이러한 노력은 다양한 파트너십의 활동 및 성과를 종합 적으로 관리하고, 평가하기 위한 파트너십의 필요성을 반영한 것이라 할 수 있다.

이와 같이 파트너십이 개발원조의 새로운 모델로 등장함에 따라, 기획 및 집행뿐만 아니라 전반적인 성과관리 및 평가 측면에서도 파트너십의 중요성이 대두되었다. 이에 국제사회는 '개도국 우선사항을 충족하는 결과중심의 협력'을 부산 글로벌 파트너십 이행을 위한 평가지표 의 제 1 지표로 설정함으로써, 공여국이 개도국의 결과 프레임워크를 이용하도록 권장하고 있 다. 이는 단기적으로는 개도국의 행정 부담 경감효과를 기대할 수 있고, 중장기적인 관점에서 는 개도국의 성과 관리 및 평가관련 역량을 강화하고 주인의식을 강화할 수 있다. 이와 동시 에, GRPPs의 경우와 같이 '파트너십'으로 구성되는 다양한 정책, 사업 프로그램의 평가 방식 및 기준을 통합함으로써 전반에 걸친 협력체계와 공동 책무성을 강화하는 방향으로 발전하고 있다. 


\section{3. $\mathrm{KOICA}$ 의 개도국과의 성과 파트너십}

\section{1 개도국과의 성과 파트너십 추진 배경}

협력단의 평가실 차원에서 성과관리를 본격적으로 추진한 것은 2010년부터이다. 원조효과 성 강화의 일환으로 개발원조 성과관리가 강조됨에 따라, 우리 원조시스템도 성과중심으로의 개선이 필요함을 인식하고, KOICA 선진화계획(2010 2015)에 근거하여 실질적인 성과관리 이행방안을 탐색하기 시작하였다. 협력사업의 종류에는 여러 가지가 있으나, 가장 비중이 큰 프로젝트 사업에 대한 성과관리를 중심으로 출발하였고, 기획-집행-평가의 단계에서 평가실 이 사업의 성과관리 프레임워크 수립 및 성과관리 계획에 근거한 모니터링 및 평가에 보다 적 극적으로 개입하는 방식으로 이루어지고 있다.

\section{〈그림 1〉 성과중심 관리의 개념}

성과관리 : 기존 예산집행률 및 산출물 중심의 사업관리에서, 결과물 및 영향 력 중심의 관리 및 평가로 전환

전통적 사업관리 및 성과관리 비교 (예시 : 직업훈련원 사업)

전통적 관리 범위

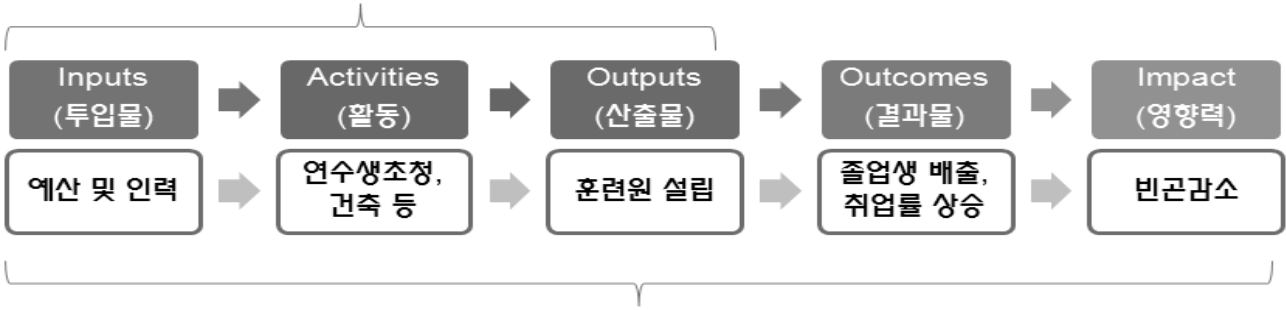

\section{성과중심관리 볌위}

성과관리 자체의 고도화뿐만 아니라, 성과관리 부문의 개도국과 파트너십 강화 또한 추진 중이다. 파트너십과 상호책임성 등이 강조되는 개발협력 패러다임의 변화에 따라 성과관리 및 평가에 있어서도 개도국과의 파트너십의 필요성이 제기 되었기 때문이다. 그렇다면 프로젝트 사업에 대한 개도국과의 성과관리 부문 협력은 어떻게 발전하여 왔는가? 아직 국제사회에서 권장하는 엄밀한 의미의 성과관리 파트너십이 현실화 된 단계는 아니나, 궁극적으로 이를 달 성하기 위한 의미 있는 진전을 이루었다. 사업 기획단계에서 수원국과 협의를 통해 성과관리 
계획을 보다 구체화하고 협력체계를 실시협의 의사록(Record of Discussion, ROD)에 명문화 하고, 성과의 모니터링 및 평가에 있어서 개도국과의 공동평가를 실시하는 등의 방식으로 개 도국과의 성과관리 파트너십을 강화하고 있다. 이에 프로젝트 사업의 기획-집행-평가 각 단 계에 있어 대표적인 개도국과의 성과관리 파트너십 사례를 소개하고자 한다.

\section{2. 개도국과의 성과 파트너십 사례}

먼저, 사업 기획단계의 성과관리 파트너십은 $\boldsymbol{\Delta}$ 사업계획상의 결과 프레임워크 협의, $\boldsymbol{\Delta}$ 성과 관리 계획(모니터링 및 평가계획 포함) 및 체계 협의, $\boldsymbol{\Delta}$ 합의된 양국 간 성과관리 협업체계의 명문화 등을 들 수 있다. 매우 당연한 수준의 사항이라고 생각할 수 있으나, 기존에는 사실상 개도국으로부터의 동의 형식에 머물렀다면, 최근에는 동등한 파트너관계로서 양국 간 실무자 간 협의를 통해 공동의 결과를 도출하는데 힘쓰고 있다.

평가실에서 관리하는 성과관리 시범사업 중 하나인 '카사블랑카 자동차 직업훈련원 건립사 업('10-'13/600만불)'의 경우, 사업 착수 조사시 수원국 주관기관(고용훈련부) 및 운영기관(모 로코자동차협회)과의 협의를 통해 성과계획 및 관리체계를 수립하였다. 동 협의 과정에서는 사업의 성과목표 및 지표에 대한 합의뿐만 아니라, 성과관리의 책임 주체까지 구체적으로 협 의하였다. 가령, 초기 및 중기성과물 수준의 지표는 자동차협회(AMICA)측이, 최종성과 수준 의 지표는 고용훈련부측이 측정하기로 잠정 합의함으로써 개도국 내 관계기관 간의 협업체계 또한 구체화하였다. 착수조사 이후에도 현지 KOICA 사무소를 통한 지속적인 협의가 이루어졌 다. 이 과정에는 성과목표와 지표의 타당성 및 적합성 검증과, 양측의 혼란을 최소화하기 위한 사용용어의 정의 구체화, 통일화 작업이 이루어졌다. 최종 성과관리계획 및 체계는 세 기관 (KOICA, 고용훈련부, 자동차협회)의 합의에 의해 결정되었으며, 양측은 모로코의 수원총괄기 관(외교부)이 $\mathrm{KOICA}$ 모로코 사무소에 관련 공식 서한을 전달하는 것으로 성과관리 파트너십 을 공식화 하였다.

\section{〈그림 2〉 사업기획단계의 성과 파트너십 추진 절차}


이와 같이 지속적인 실무자간의 의사소통을 통해 성과의 모니터링 및 평가계획에 대한 협의 및 검증 절차가 이루어진 것이다. 아래〈표2〉에서 확인할 수 있는 바와 같이, 모로코측 관계기 관과의 협의를 통해 성과지표를 현지에서 보편적으로 사용되며 측정 가능한 것으로 구체화 하 는 성과를 거두었다. 또한 이러한 과정을 통해 모로코 관계기관의 사업에 대한 이해도와 주인 의식을 고취할 수 있었으며, 비록 모로코의 공식적인 직업훈련 관련사업 결과 프레임워크를 직접 사용하지 않더라도 모로코측의 의견 반영을 통해 사업성과 프레임워크의 현지화가 가능 하였다.

〈표 2〉 성과지표 협의 과정 요약6)

\begin{tabular}{|c|c|c|c|c|c|c|}
\hline & \multicolumn{2}{|c|}{$\begin{array}{c}\text { 수정요청안 } \\
\text { (협모로코-524/2011.10.25) }\end{array}$} & \multicolumn{2}{|c|}{$\begin{array}{c}\text { 평가실 제안 } \\
\text { (협평가-804/2011.10.28) }\end{array}$} & \multicolumn{2}{|c|}{$\begin{array}{l}\text { 수원기관 최종합의안 } \\
\text { (2011.12.22) }\end{array}$} \\
\hline & 성과 & 지표 & 성과 & 지표 & 성과 & 지표 \\
\hline $\begin{array}{l}\text { 최종 } \\
\text { 성과 }\end{array}$ & $\begin{array}{l}\text { 청년 및 } \\
\text { 노동자의 } \\
\text { 증가 }\end{array}$ & $\begin{array}{l}\text { 1) 졸업생의 취업률 } \\
\text { 및 insertion rate } \\
\text { 2) 수혜자의 } \\
\text { 직장유지율 }\end{array}$ & $\begin{array}{l}\text { 모로코 측 } \\
\text { 의견 수렴 }\end{array}$ & $\begin{array}{l}\text { 1) 졸업생의 취업 } \\
\text { 률 및 insertion } \\
\text { rate } \\
\text { 2) 수혜자의 } \\
\text { 직장유지율 } \\
\text { 3) 졸업생 역량과 } \\
\text { IFMIAC 훈련 } \\
\text { 프로그램에 대한 } \\
\text { 고용주 만족도 }\end{array}$ & $\begin{array}{c}※ \text { 수정요청 } \\
\text { 안 반영 }\end{array}$ & $\begin{array}{l}\text { ※ 수정요청안 반영 } \\
\text { 1) 졸업생의 취업률 } \\
\text { 및 insertion rate } \\
\text { 2) 수혜자의 직장유 } \\
\text { 지율 } \\
\text { 3) 졸업생 역량과 } \\
\text { IFMIAC 훈련 프로 } \\
\text { 그램에 대한 고용 } \\
\text { 주 만족도 }\end{array}$ \\
\hline \multirow{3}{*}{$\begin{array}{l}\text { 중기 } \\
\text { 성과 }\end{array}$} & & $\begin{array}{l}\text { 2년과정 } \\
\text { 학생들의 } \\
\text { 졸업율 }\end{array}$ & $\begin{array}{l}\text { 모로코 측 } \\
\text { 의견 수렴 }\end{array}$ & $\begin{array}{l}\text { 1) 2년과정 학생 } \\
\text { 들의 졸업율 } \\
\text { 2) 2년과정 학생 } \\
\text { 들의 TS 자격 } \\
\text { 증 취득률 }\end{array}$ & $\begin{array}{l}\text { ※ 수정요청 } \\
\text { 안 반영 }\end{array}$ & $\begin{array}{l}\text { ※ 수정요청안 반영 } \\
\text { 1) } 2 \text { 년과정 학생들의 } \\
\text { 졸업율 } \\
\text { 2) } 2 \text { 년과정 학생들의 } \\
\text { TS 자격증 취득률 }\end{array}$ \\
\hline & & $\begin{array}{l}\text { 1) Employees } \\
\text { satisfaction in the } \\
\text { sector about the } \\
\text { training program } \\
\text { of IFMIAC and the } \\
\text { capacity of the } \\
\text { graduates }\end{array}$ & \multirow[t]{2}{*}{ 삭제 } & $\begin{array}{l}\text { 최종성과 지표로 } \\
\text { 이동 }\end{array}$ & 삭제 & $\begin{array}{l}\text { ※ 수정요청안 반영, } \\
\text { 삭제 및 지표 이동 }\end{array}$ \\
\hline & & 삭제 & & $\begin{array}{l}\text { 모로코 측 의견 } \\
\text { 수렴 }\end{array}$ & 삭제 & ※수정요청안 반영 \\
\hline
\end{tabular}

6) 카사블랑카 자동차 직업훈련원 건립사업 성과관리 계획 최종합의안(KOICA, 2011) 
이와 같이 사업성과 관리 체계를 공식화하고 모로코 관계기관간의 업무분담을 명확히 함으 로써 사업종료 후에도 모로코의 사업성과에 대한 지속적인 관리를 기대할 수 있다. 또한 지속 적으로 축적된 성과지표 데이터는 객관적인 성과 입증을 위해 필수적인 것으로, 추후 공동평 가를 통한 상호책임성 확보에 중요한 기반을 제공한다. 사업성과에 대한 상호 책임성을 보다 확고히 하고, 개도국의 성과관리 참여를 보다 공식화 하기 위해서는 사업기획 단계에서 협의 된 사항을 문서화 하는 것이 좋은데, 이는 사업의 실시협의 의사록 상의 모니터링 및 평가 부 문에 양국의 공동평가 의무를 명시하는 등의 방식으로 가능하다.

두 번째로, 사업 집행단계의 성과 파트너십 사례로는 '나이지리아 직업훈련원 건립사업 ('10 '13/350만불)'의 중간평가를 소개하고자 한다. 동 사업은 사업의 기획단계에서는 파트너 와 성과계획 및 관리체계에 대한 긴밀한 협의가 다소 부족하였으나, 사업 집행단계에서 개도 국과의 성과관리 파트너십을 구축한 사례이다. 또한 이는 $\mathrm{KOICA}$ 나이지리아 사무소를 중심으 로 구성된 파트너십이라는 점에서 주목할 만하다. KOICA 나이지리아 사무소는 중간평가시 나 이지리아 측과 공동 세미나를 개최하여 사업에 대한 의견을 공유하고, 현지 전문가를 활용해 평가를 시행함으로써, 사업 기획시 부족했던 현지성과 시스템을 고려한 성과 프레임워크를 구 체화 하였다. 또한 구체화된 성과 프레임워크를 기반으로 지표 데이터 수집 또한 실행함으로 써 추후 성과평가를 위한 기반도 구축하였다. 특히, 현지 전문가를 활용한 점은 현지성과 시스 템에 대한 이해와 $\mathrm{KOICA}$ 사업에의 반영, 나이지리아 정부와의 의사소통을 원활히 하는데 크 게 기여한 것으로 판단된다. ${ }^{7)}$

세 번째로, 평가 단계의 대표적인 사례로는 '민주콩고공화국(이하 DR콩고) 말라리아 퇴치사 업('09-'10/20억)'의 종료평가를 꼽을 수 있다. 이 사례는 나이지리아 사례보다 발전된 형태의 개도국과의 성과관리 파트너십 사례로, 수원기관의 평가 시스템을 활용한 종료평가 사례이다. 동 평가에서는 $\mathrm{DR}$ 콩고 말라리아 사업의 성과를 정량적으로 증명하기 위해 KOICA DR콩고 사 무소를 주관으로 PNLP8) 평가실에서 종료시점 성과측정(endline survey)을 실시하였다.

PNLP는 DR콩고 보건부 산하의 말라리아 퇴치기구로, 말라리아 관련 사업을 총괄하는 기관 이다. 평가시스템은 주기적인 모니터링 시스템과 전략적인 평가 시스템으로 구성되어 있으며, 필요시 여타 학술, 연구기관9)과 협력하여 평가를 수행한다. 기관의 특성상 말라리아 관련 프

7) 코기주 직업훈련원 건립사업 중간평가 최종결과보고(KOICA, 2012)

8) Programme National de Lutte contre le Paludisme

9) Public Health School of Kinshasa, Lubumbashi, Goma, University of Kinshasa, Pharmaceutical School, National Institute of Bio-Medical Research(INRB) 등 
로그램을 지원하는 모든 공여기관과 협력관계를 유지하며, 공여기관과 파트너십을 통해 국가 차원의 DR콩고 말라리아 퇴치 프로그램 성과에 대한 공동평가를 수행한다. ${ }^{10)}$ PNLP의 평가 절차는 아래 그림과 같이 4 단계로 구분할 수 있다.

\section{〈그림 3〉PNLP의 공동평가 추진 절차11)}

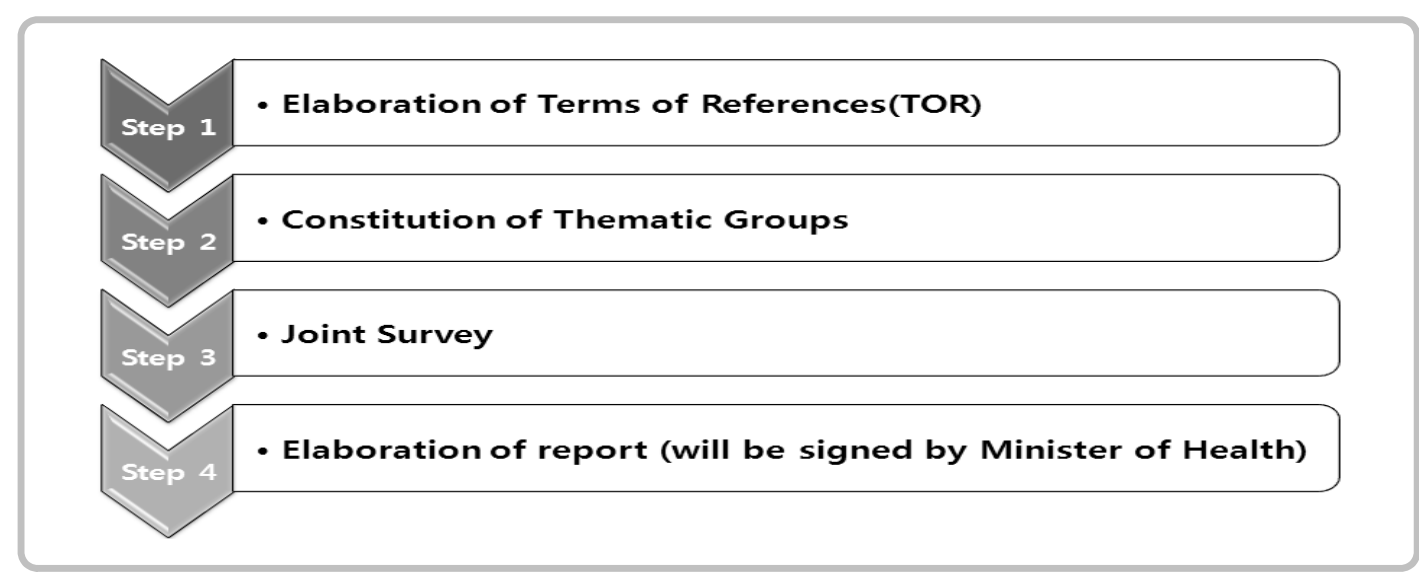

지난 12 월 '평가 파트너십 증진을 통한 수원국의 평가 역량 강화-Strengthening Partnership in Evaluation Work)'를 주제로 개최된 2012년도 제4차 개발평가 세미나에서는 동 평가의 당 시 DR콩고측 담당자인 PNLP 소속 Dr. AIME YIYI MANTEMPA가 동 평가의 절차 및 시사 점에 대해 공유하였다. Dr. YIYI가 동 발표에서 제시한 수원국이 판단하는 공동평가의 장점은 직접 현장조사를 통한 성과평가가 가능하다는 것이며, 공여국별 상이한 평가기준 및 방법을 적용하지 않고, 종합적인 성과 점검이 가능하다는 점이다. 제한요소로는 PNLP의 공동평가가 절차상 현지실사를 포함하고 있어, 도로사정 등으로 접근이 불가능한 지역의 평가는 불가하다 는 점을 제시하였다.

종료평가 과정에서 $\mathrm{KOICA}$ 는 PNLP 평가실에서 설문지를 개발하고, 수혜지역 의료인력 및 수혜자 표본 대상 설문조사를 실시하도록 지원하였다. 수원기관의 평가시스템을 이용하고 그 결과를 양국에서 모두 내부 결과보고 자료로 활용함으로써 불필요한 행정소모를 줄이고, 사업

10) 2012년 7월, DR콩고 말라리아퇴치기구 및 궁여국 간 2011년 사업 추진에 대한 공동평가PNLP Performance Review, Joint evaluation)가 진행되었으며, 협조기관은 WHO, International Fund, SANRU, USAID, UNICEF, DFID, World Bank 등이다. KOICA의 경우 2011년도 말라리아 사업 관련 추진내역이 없어, 평가에 대한 재정적, 기술 적 지원은 하지 않았으나 최종보고회에 참석한 바 있다.

11) 2012년도 제4차 개발평가 세미나, "Evaluation System of Malaria Control Program (PNLP) and Participative Evaluation in DRC(AIME YIYI MANTEMPA, MD, MPH)' 발표자료 인용 
성과에 대한 공동책임을 확인하며, 추후 사업 추진 시 참고할 만한 교훈사항을 공유하여 사업 추진의 방향성 또한 공유하였다. 아울러, 사업평가를 하는 과정에서 우리 측의 기술자문 등을 통해 수원국의 역량강화를 도모하였다. 이러한 과정을 통해 사업성과에 대한 상호책임성을 확 보하고, 상호 역량강화와 같은 학습효과를 극대화 한 것이다.

네 번째로, 보다 광의의 성과부문 파트너십 사례로는 '에티오피아 아르시존 가족계획 및 모 자보건 증진사업('08-'10/340만불)'의 영향평가 사례를 들 수 있다. 이는 성과관리 중에서도 특히 평가 파트너십 사례이다. 동 평가는 한국 개발협력사업 대상으로는 최초로 시도된 영향 평가로써 과학적이고 객관적인 성과 입증에 기반한 가족계획 및 모자보건 사업의 모델수립을 위한 근거제시를 위해 수행되었다.

영향평가 수행에는 다양한 차원의 파트너들이 평가 참여함으로써 거시적인 차원에서 미시 적인 차원까지 복합적인 형태의 평가파트너십을 이루었다. 먼저 중앙정부 차원에서는 평가의 목적 및 절차 등을 설명하고, 평가수행에 대한 승인을 얻는 협력이 이루어졌다. 이는 평가수행 을 위해 학술적으로 필요한 윤리적 문제를 해결하기 위한 목적도 있지만, 또 한편으로는 이러 한 과정을 통해 중앙정부 관계자의 사업과 평가에 대한 인식 및 관심을 유도함으로써 자연스 럽게 평가결과의 피드백 채널을 확보하였다. 지방정부는 보다 실무적인 협력 관계로서 평가에 필요한 관련 자료를 제공하고, 현지 설문조사에 협조하는 등 평가의 실질적인 수행과정에 협 력하였다. 또한 기관차원의 협력은 아니나, 현지 보건요원이 성과지표 데이터 수집 역할을 수 행함으로써 다양한 차원의 평가파트너십을 완성하였다.

\section{〈그림 4〉에티오피아 영향평가 수원국과의 다양한 차원의 파트너십12)}

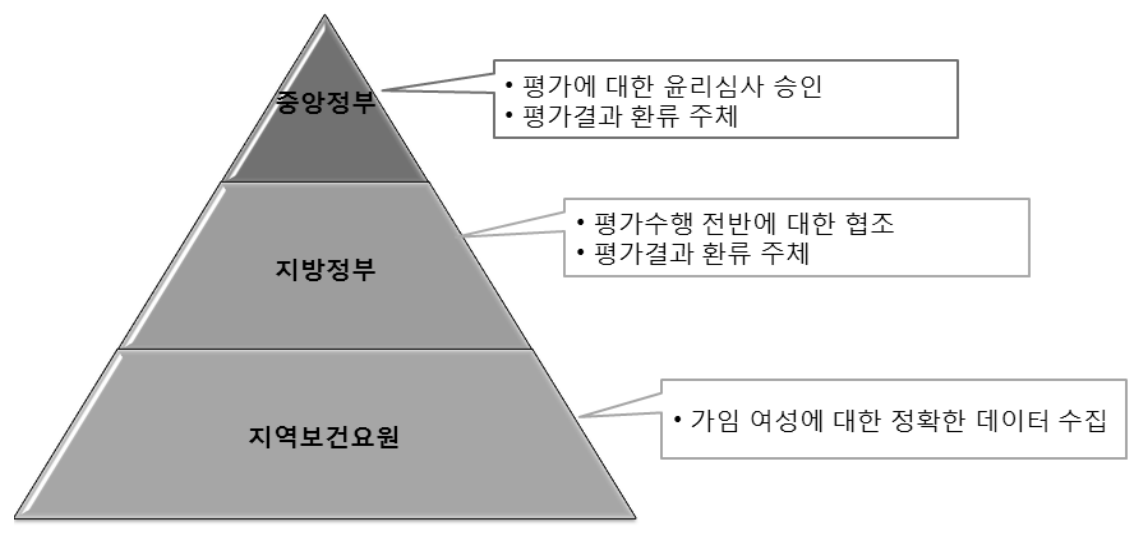

12) 2012년도 제4차 개발평가 세미나, 'Evaluation Partnership from KOICA's case(KOICA 평가실 강종려 직원)' 발표 자료 인용 
이러한 방식의 평가는 국제사회에서 정의하는 엄밀한 의미의 평가 파트너십(개도국의 결과 프레임워크를 활용한 평가)은 아니나, 평가의 과정에 다양한 계층의 개도국 파트너를 포함시 킴으로써, 평가의 파급효과를 극대화 할 수 있다는 장점이 있다.

마지막으로, 협력단의 개도국과 평가 파트너십 구축을 위한 제도적인 장치에 대해 소개하고 자 한다. 협력단은 프로젝트 사업 평가에 있어 개도국과의 평가파트너십을 보다 보편적으로 적용하기 위해, 2012년 '수원국과의 공동평가를 위한 종료평가 양식'을 수립, 적용하였다. 동 양식은 개발사업 결과에 대한 개도국 주인의식 제고 및 참여 증진을 위하여, 사업 종료 평가시 개도국 파트너의 의견 수렴하기 위해 수립되었다. 이 양식은 ' 12 년 상반기에 수립되어, ' 12 년 도 하반기 이후 지역부서에서 수행하는 종료평가부터 적용되었다. 평가방식은 종료평가시 해 당 서식을 활용하여 수원국 관계기관 의견 수렴 후, 최종 종료평가 보고서에 포함하도록 제도 화 하였다.

〈표 3〉 수원국과의 공동평가를 위한 종료평가 양식 주요내용

\begin{tabular}{|c|c|c|}
\hline 문 항 & 주요 확인 사항 & $\begin{array}{c}\text { 관련 OECD/DAC } \\
\text { 평가 기준 }\end{array}$ \\
\hline 1. 종합 의견 & $\begin{array}{l}\text { 사업목표 달성 기여도, 투입 자원의 } \\
\text { 효율성, 사업결과의 효과성, 사업의 } \\
\text { 강약점 등 }\end{array}$ & $\begin{array}{c}\text { 적절성, 효율성, } \\
\text { 효과성 }\end{array}$ \\
\hline $\begin{array}{l}\text { 2. 수원국 차원의 사업 } \\
\text { 관리 전략 수립 여부 }\end{array}$ & $\begin{array}{l}\text { 종료사업 운영 계획, 예산.인력 활용 } \\
\text { 방안 등 전략 수립 여부 }\end{array}$ & \multirow{2}{*}{$\begin{array}{l}\text { 지속가능성 } \\
\text { (사후관리) }\end{array}$} \\
\hline $\begin{array}{l}\text { 3. 사업 결과 관리를 } \\
\text { 위한 추가 필요 사항 }\end{array}$ & $\begin{array}{l}\text { 물자, 기술협력 및 자국 정부 지원 등 } \\
\text { 추가 필요 사항 }\end{array}$ & \\
\hline 4. KOICA에 제언 & $\mathrm{KOICA}$ 의 업무 수행 과정의 적절성 & - \\
\hline
\end{tabular}

이는 기관차원에서 평가부문의 개도국 파트너와의 협력을 의무화함으로써, 사업관리자의 공여국 중심 접근방식으로부터의 전환을 유도하고, 사업성과에 대한 상호책임성을 확보할 수 있다는 차원에서 의의가 있다. 


\section{4. 시사점}

일반적으로 성과 파트너십에 있어 개도국의 참여 정도는 다양한 형태로 나타날 수 있다. 아 래〈그림 6〉에서 보는 바와 같이, 참여의 정도가 심화될수록 의사결정의 주체성 높아지고 형 평한 파트너십의 실현이 가능함을 알 수 있다.

〈그림 5〉 참여의 정도13)

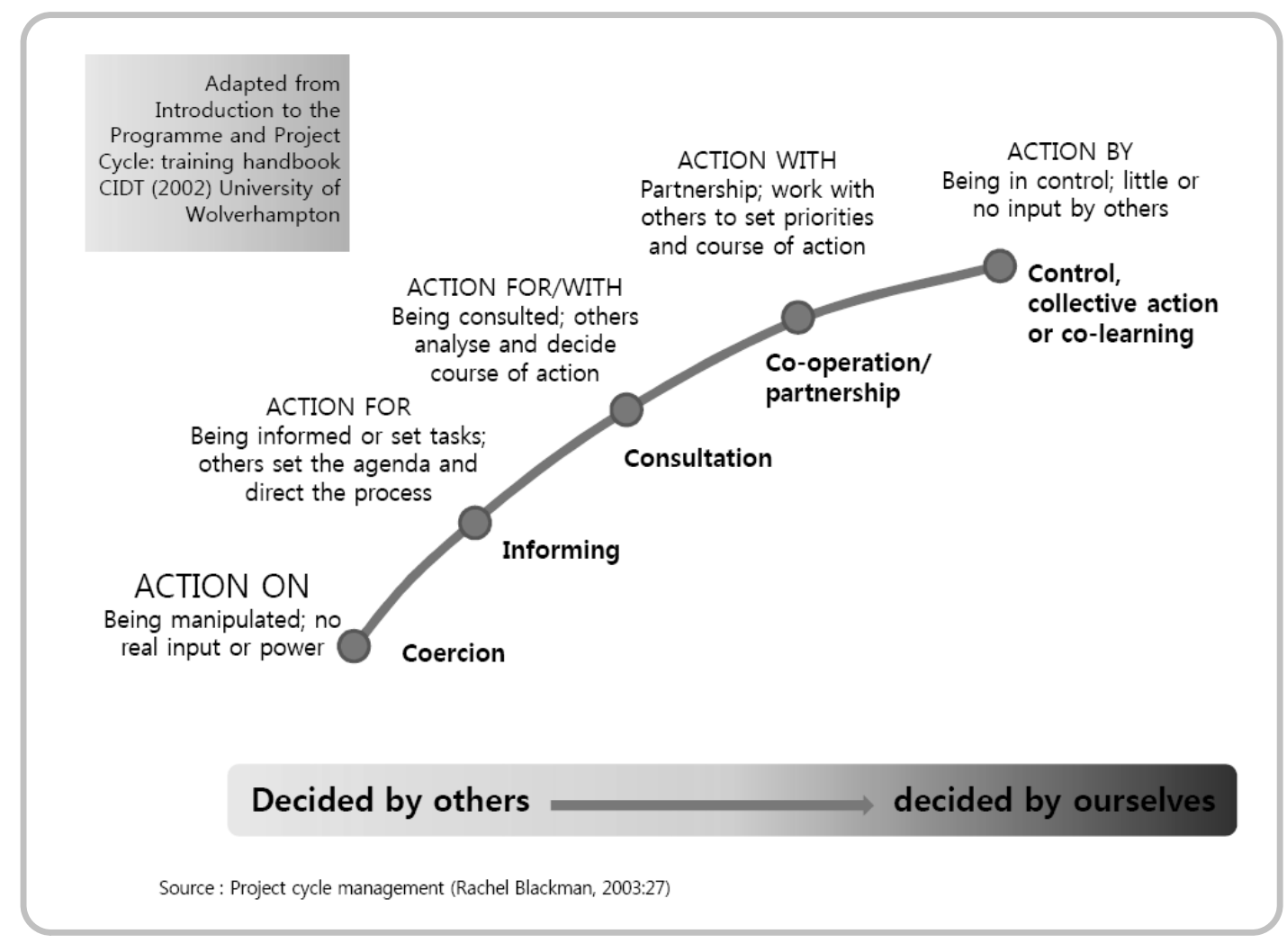

여기서 우리가 주목해야할 점은 이러한 참여가 정책 및 전략 차원에만 해당하는 것이 아니 라는 점이다. 벨기에 정부의 $\mathrm{NGO}$ 사업 파트너십 평가보고서에서는 자국의 $\mathrm{NGO}$ 개발원조 사 업 추진에 있어 정책, 전략 차원의 파트너십에 대한 인식과 반영은 뛰어나나, 실제 집행차원에 서 파트너십의 이행은 부족하다는 점을 지적한 바 있다14). 이와 더불어 이 보고서에서는 실무

13) 2012년도 제4차 개발평가 세미나, 'Participatory Development, Monitoring and Evaluation(KOICA 조한덕 기획 예산실장' '발표자료 재인용 
차원의 긴밀한 협력이 개도국의 역량강화와 진정한 파트너십 구축에 필수적임을 강조하였다. 정책 및 전략 차원의 개도국의 참여와 파트너십은 선언적인 의미를 가지며 정책결정론자들의 의지를 반영한다는 측면에서 중요하나, 이에 근거한 집행 및 평가차원의 지속적인 협력은 개 도국의 실질적인 참여를 가능케 한다는 점에서 매우 중요하다.

이러한 의미에서 우리는 앞에서 소개한 한국국제협력단이 진행하고 있는 개도국과의 성과 관리 파트너십 사례에 주목할 필요가 있다. 이는 국제사회에서 정의하는 엄밀한 의미의 성과 관련 파트너십보다는 보다 폭넓은 차원의 것이지만, 사업의 기획-집행-평가 단계의 사업의 전 과정에 거쳐 실질적인 파트너십을 유도한다는 차원에서 의의가 있다.

모로코 사례에서 살펴본 바와 같이 사업 기획단계에서의 개도국과의 성과 파트너십 형성은 개도국의 사업에 대한 이해도와 주인의식을 고취할 수 있었으며, 우리측 또한 모로코의 직업 훈련 관련사업 성과 프레임워크에 대한 학습의 기회가 되었다. 또한 이러한 과정을 통해 사업 성과 관리 체계를 공식화하고 모로코내 이해관계자간의 업무분담을 명확히 함으로써, 사업 종 료후에도 개도국의 주인의식을 기반으로 한 성과관리를 기대할 수 있다. 또한 사업 기획단계 의 성과 파트너십 형성은 추후 성과에 대한 상호책임성 확보에 중요한 기반을 제공한다.

사업 집행단계의 나이지라아의 사례는 현지 전문가 활용을 통해 국내의 지역 전문가가 부족 한 현실적인 한계를 극복하고, 평가과정에 직접 수혜기관뿐 아니라 수원총괄 기관 및 나이지 리아 유관기관 인사들의 관심을 유도하여 그들의 의견을 수렴함으로써 상호 역량강화와 같은 학습효과를 창출한 것으로 평가된다. 또한 평가과정에서 나이지리아 정책결정의 중심에 있는 관계자들을 대상으로 사업성과 및 프로젝트 목표 달성의 장애요소 등을 알림으로써, 사업성과 제고를 위한 발판을 제공한 것으로 사료된다. 또한 이러한 현지 사무소를 주축으로 하는 개도 국과의 성과 파트너십 구축은 $\mathrm{KOICA}$ 차원에서는 평가를 통해 사업에 대한 자료 및 정보축적 이 가능하고, 현장에서 직접적인 사업의 질적 관리가 용이하다는 장점이 있다. 아울러 개도국 차원에서는 직접관계자가 평가과정 참여함으로써 현안파악 및 즉각적인 대응이 가능하며, 이 를 통해 사업에 대한 주인의식 강화될 수 있다는 이점이 있다.

사업 평가단계의 에티오피아 사례와 같은 파트너십은 평가의 과정에 다양한 계층의 개도국 파트너를 포함시킴으로써, 평가의 파급효과를 극대화 할 수 있다는 측면에서 시사 하는바가

14) Kingdom of Belgium, Foreign Affairs, Foreign Trade and Development Cooperation(2010). Evaluation of NGO Partnerships aimed at capacity development. 
크다. 개도국 파트너들이 평가과정에 직접 참여 및 기여하고, 평가 수행 중 긴밀한 협력을 통 해 개도국 파트너들의 평가내용에 대한 인지도를 높여, 파트너들이 자연스럽게 평가결과를 체 득하여 평가결과에 근거한 실질적인 변화를 기대할 수 있기 때문이다.

또한 개도국과의 평가파트너십을 위한 제도적 장치인 '수원국과의 공동평가를 위한 종료평 가 양식은 기관차원에서 개도국의 사업성과에 대한 의견수렴 절차를 공식화 하고, 이를 통해 공여국 중심에서 개도국 중심의 사업접근방식 환경을 조성한다는 차원에서 의미가 있다.

KOICA의 기존 성과관련 파트너십은 개도국에게 우리측 결정사항을 알리는 'Informing' 차 원에 해당하였다. 그러나 성과관리 고도화 및 개도국 파트너와의 협력체계 강화를 통해 추구 하는 성과 파트너십은 개도국을 보다 수평적인 파트너로 인식하고, 그들의 적극적인 참여를 보장하는 'Consultation' 및 'Co-operation/partnership'으로 점차 발전하고 있다. 국제사회 의 규범에서 정의하는 '개도국 우선사항을 충족하는 결과중심의 협력'은 이보다 한 단계 발전 한, 개도국이 주도권을 가지고 있는 'Control, collective action or co-learning'에 가깝다 할 수 있다. 국제사회의 담론은 우리의 원조성과를 평가하는 지표가 된다는 측면에서 존중할 필 요가 있으나, 현실적인 고려 없는 무조건적 도입은 부작용을 초래할 수 있다. 따라서 우리나라 의 개발협력 환경에서는 점진적인 성과관리 및 파트너십 부문 강화를 통해 개도국과의 성과 파트너십을 제고할 필요가 있다.

\section{5. 맺음말}

개도국과의 성과관리 파트너십은 공여국-개도국 간의 원조효과성 대한 공동책임성을 제고 하고, 개도국의 자발적 참여를 통한 개도국의 관련 역량 향상을 도모할 수 있다는 점에서 장려 되고 있다. 협력단은 이러한 국제사회의 흐름에 부응하여 프로젝트 사업을 중심으로 개도국과 의 성과 파트너십을 추진하고 있다. 위에서 살펴본 사례와 같이 협력단에서 현재 진행되고 있 는 개도국과의 성과관리 파트너십은 성과파트너십 강화를 통한 원조의 효과성 제고 및 개도국 의 역량증진을 궁극적인 목표로 하며, 사업의 기획-집행-평가 단계에 거쳐 다양하다. 또한 이 는 국제사회에서 정의하는 엄밀한 의미의 성과관련 파트너십보다는 광의의 의미와 활동을 포 함하고 있으나 국내 개발원조 환경을 고려할 때 현실적인 대안으로 활용될 수 있다. 
개도국의 시스템 활용이 아닌 별도의 성과프레임워크를 수립해야 한다는 점이 단점으로 지 적될 수 있으나, 사업 기획단계에서 집행, 그리고 평가에 이르기까지 실무적인 소통 및 협력을 통한 파트너십 구축은 과정 공유를 통한 학습효과가 상당하다. 실제로 앞서 소개된 $\mathrm{KOICA}$ 의 성과관리 파트너십 사례 사업은 개도국의 사업성과 및 추진방향에 대한 높은 관심과 의지로 대부분 2차 사업으로 연계되어, 성과 파트너십이 개도국의 주인의식 및 상호책임성 제고에 긍 정적인 영향이 있음을 짐작할 수 있다. 또한 실질적으로 우리의 원조 실행체제가 아직 국제사 회에서 논의되는 파트너십에 적극적으로 참여하기 위한 기반을 구축하는 단계이므로, 성과관 리 및 평가 또한 실행체계의 점진적인 변화와 더불어 이루어지는 것이 바람직하다 하겠다. 


\section{참고문헌}

임소진(2012). 부산파트너십 이행 평가지표 수립방향 및 전략연구. 개발협력 정책과 이슈 제 10 호. 한국국제협력단

임소진(2012). 한국 ODA의 부산 글로벌 파트너십 평가지표 이행방안. 개발협력 정책과 이슈 제 15 호. 한국국제협력단

카사블랑카 자동차 직업훈련원 건립사업 성과관리 계획 최종합의안(KOICA, 2011)

코기주 직업훈련원 건립사업 중간평가 최종결과보고(KOICA, 2012)

$\mathrm{DR}$ 콩고 말라리아퇴치사업 종료시점 성과측정 결과 보고(KOICA, 2012)

Kingdom of Belgium, Foreign Affairs, Foreign Trade and Development Cooperation(2010). Evaluation of NGO Partnerships aimed at capacity development.

World Bank(2007). Sourcebook for Evaluating Global and Regional Partnership Programs: Indicative Principles and Standards. 